\title{
Awareness, Knowledge and Prevention Practices Related to Lassa Fever Among Residents of Rural Communities in Southwest Nigeria: Implications for Prevention and Control
}

Olukemi Aromolaran ( $\nabla$ olukemi.aromolaran@bowen.edu.ng )

\section{Research Article}

Keywords: Lassa fever, Awareness, Knowledge, Prevention practices, Endemic, Nigeria.

Posted Date: February 5th, 2021

DOI: https://doi.org/10.21203/rs.3.rs-170442/v1

License: (c) (1) This work is licensed under a Creative Commons Attribution 4.0 International License. Read Full License 


\section{Abstract}

Background: Lassa fever (LF) is a haemorrhagic illness caused by Lassa virus. The primary reservoir of the virus is the multimammate rat, Mastomys natalensis. More than 3,000 laboratory-confirmed cases of Lassa fever and over 800 deaths have been recorded in Nigeria. This could be attributed to poor rat control and poor sanitation especially in the rural communities where the rats are often found. Increasing awareness and health education about LF have been advocated for its prevention and control. This study investigated the level of awareness, knowledge and prevention practices related to LF among residents in rural communities within Iwo and Ayedire Local Government Areas, Osun State, southwest Nigeria sequel to an awareness campaign.

Methods: Structured questionnaire was administered within rural communities in Iwo and Ayedire and 675 participants responded for the survey by a random sampling technique. Descriptive statistics, Chisquare test of association $(p=<0.05)$ and logistic regressions were used to determine associations between demographic variables, level of knowledge and prevention practices.

Results: The average age range was 25-39 years, 365 (54.07\%) were male, 270 (40\%) were married, 199 (29.48\%) had up to secondary school education and 536 (79.41\%) have heard about LF before.

Respondents in Iwo town were more aware of LF than respondent from Ayedire. Only $3(0.44 \%)$ had good knowledge of the transmission and symptoms of the disease and $304(45.04 \%)$ do not have effective means of preventing rats into their homes. About 296 (43.85\%) will go to a hospital if symptoms occur, while 118 (17.48\%) will do self-medication. Forty-four (6.52\%) were aware of good prevention practices. Logistic regression analysis showed that respondents aged 25-39 years were significantly more aware of Lassa fever than other age groups. Educated and married respondents showed significant relationship with good prevention practices than those without education and were not married.

Conclusions: Although, the awareness of LF among the respondents was high, only very few had good knowledge of the transmission and symptoms of the disease. Therefore, it is important for the people to be well informed about the disease and good prevention practices in order to curtail the spread.

\section{Background}

Lassa fever (LF) is an acute viral haemorrhagic illness endemic in West Africa, with increased prevalence reported from Sierra Leone, Guinea, Liberia, and Nigeria [1-4]. Not less than 100,000-300,000 people are infected annually, with approximately 5,000 deaths in West Africa alone [5,6]. Although endemic in West Africa, there have been cases of Lassa fever transported to Europe and some other part of the world by travellers from the endemic regions $[7,8]$. Several reports of LF outbreak have been documented in Nigeria (Fig. 1) [2, 3] after the first case in Lassa town, Borno State, Northeast, Nigeria in 1969, when two missionaries died as a result of the disease [5,9-11]. Nigeria is presently experiencing LF outbreak with a case-fatality ratio (CFR) of 20.6\%. More than 3,004 laboratory-confirmed cases of LF and 867 deaths have been reported in Nigeria, between January 2014 and December 2020 (Fig. 2) [4]. The number of 
cases is increasing over the year, spreading from 13 states in 2014 to 29 states in 2020 . This could be attributed to poor rat control and poor sanitation especially in the rural communities where the rats are often found, inadequate knowledge of the disease, and increased diagnosis in four urban centers within the country. Functional diagnostic laboratories give access to carry out more tests and early detection of $\operatorname{LF}[4-5,11-13]$.

Lassa fever is transmitted to humans by the Lassa virus (LASV) [1, 5, 14-15]. It is a single-stranded RNA virus, belonging to the family Arenaviridae [9]. The primary reservoir of the virus is the multimammate mouse, Mastomys natalensis, $[4,9,16]$ although recent studies have identified $M$. erythroleucus and Hylomyscus pamfi as possible carriers of the LASV [17]. Infected mice are carriers of the virus, though asymptomatic but are capable of discharging the Lassa virus through urine, feaces, saliva, respiratory secretions, and exposed blood vessel into the environment [1, 5, 18-19]. Mastomys natalensis is commonly found in Sub-Sahara Africa, where up to $30 \%$ can be carriers of the LASV in endemic regions $[9,12]$. The primary route of transmission of Lassa fever is through contact with infected rodent's feaces, urine, or blood, while secondary route of transmission includes direct contact with the body fluid of an infected person $[16,20]$. The consumption of infected rodents is another possible means of transmission. Due to the stability of Arenavirus, infections via the aerosol route in non-human primates have been documented [21-23]. Infection could occur six to twenty-one days after exposure to the virus [16, 24]. Eighty percent of infected people are mild or asymptomatic $[16,17,25]$. Symptoms usually begin with flulike illness, fever, malaise, which may be accompanied by cough, sore throat, severe headache, chest and abdominal pain, vomiting, diarrhea; and may later result in bleeding from the mucosa openings, severe haemorrhagic fever, facial edema, multi-organ dysfunction, which could eventually lead to death $[15,17$, $26,28]$. Infection of fetus and loss of the fetus in $90 \%$ of cases in pregnant women is common [22]. There could be hearing impairment in one-fourth of infected individuals who survive the disease and hearing returns partially after 1-3 months [24]. One in five cases of infection results in severe disease [29], and one to fifteen percent of severe cases may lead to death. Lassa fever could result in death within fourteen days in fatal cases and $25 \%$ of recovered cases could lead to deafness [15]. Presently, there is no vaccine for Lassa fever, but an antiviral drug (Ribavirin) has been found effective if administered within the early days of the infection [30]. However, there is no document to support the use of Ribavirin as a postexposure prophylactic treatment for Lassa fever [15].

Seventy-five percent of confirmed cases in Nigeria are within Ondo (36\%), Edo (32\%), and Ebonyi (7\%) [4, $15,29]$. Accessing the level of knowledge of LF among the residents of Osun State, which is the central state connecting five other states in southwest Nigeria (Fig. 1), is pivotal to its control in Nigeria. This is because; an outbreak in Osun State could easily spread to other connecting states and across southwest Nigeria. Ondo State is the highest risk state (36\% of the laboratory-confirmed cases) in Nigeria and it shares a border with Osun State. Two laboratory-confirmed cases have already been reported in Osun State, and the number could increase shortly, largely because of inter-border local trade migration. Therefore, it is important to assess the level of awareness, knowledge, and preparedness of the residents of Osun State, in order to prevent an outbreak within the State. Although, there had been great enlightenment in many urban cities within the countries; there is a dearth of information on the level of 
awareness, knowledge, and preventive practices in many towns and villages in Nigeria. These are noted to be at greater risk to Lassa virus infection because that is where Mastomys rats are commonly found [ 1 , $5,15,31]$.

This study was carried out within Iwo and Ayedire Local Government Areas (LGAs) in Osun State, as representative local communities to determine the level of awareness, knowledge, and prevention practices among the residents, so as to present the knowledge gap and to serve as a first-line measure to curtail the spread of Lassa fever in Osun State, Nigeria.

\section{Methods}

Study area and design

Local communities within Iwo and Ayedire LGAs, Osun State, southwest Nigeria were included in the cross-sectional study between February and March 2020. Iwo is situated latitude $7^{\circ} 38 \triangle 06 \otimes \mathbb{N}$ and

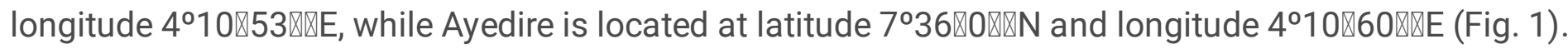
The geographical area and population of Iwo and Ayedire are $214 \mathrm{~km}^{2}$ and $262 \mathrm{~km}^{2}$, and 191,377 and 75,846 , respectively [31]. The towns experience two alternate seasons: the wet season which occurs in March to October and the dry season that stretches from November to February. The annual rainfall is about $1700 \mathrm{~mm}$, while relative humidity ranges between 30\% in January - March and 70\% in April December. Temperature is fairly constant with the day temperature ranging from 31 to $34^{\circ} \mathrm{C}$ and night temperature ranging from 24 to $28^{\circ} \mathrm{C}$. Farming and petty trade are the mainstay of their economy.

A random sampling technique was employed in this study and a total of 675 respondents were interviewed, using a structured questionnaire with a focus on the demographic characteristics, level of awareness, knowledge, and preventive practices of Lassa fever. The research assistants were trained on how to administer the questionnaire prior to data collection. The interview was conducted person to person after receiving the verbal consent of the respondents. The knowledge of the respondents about Lassa fever was investigated using a total of 24 questions. A score was allocated to each correct answer with a maximum of 24 scores. Respondents who scored $70 \%$ and above were classified as having 'good knowledge', while below 70\% were classified as having 'poor knowledge' [6].

Descriptive statistics was utilized and data obtained were presented as frequencies and percentages. Data were analyzed using the Statistical Package for Social Sciences (SPSS) software program for Windows (Version 20.0). Chi-square test of association, with $p$ set as $<0.05$ was used to determine associations between demographic variables and level of knowledge. Binary logistic regression was used to determine significant independent variables for predicting awareness and knowledge/prevention practices.

\section{Results}


Six hundred and seventy-five respondents took part in the survey, among which, 310 (45.93\%) were females, while $365(54.07 \%)$ were males (Table 1$)$. The average age range was $25-39$ years. There were 206 Muslims (30.52\%) and 327 Christians (48.44\%), while 42 (6.22\%) respondents did not give information about their religion. The proportion of respondents who were single, married, divorced, widow/widower were $37.33 \%, 40 \%, 15.11 \%$, and $7.56 \%$, respectively. Ethnicity distribution among the respondents was Yoruba (44.44\%), Igbo (29.48\%), Hausa (16.15\%) while only $7.11 \%$ were Fulani. The percentage of respondents who had secondary school education was $29.48 \%, 24.59 \%$ had university degree, while about $15.11 \%$ do not have access to any form of formal education. Approximately $25 \%$ were jobless, $13.93 \%$ were farmers, $24.15 \%$ were traders, while $24.15 \%$ engage in office work. The source of information about Lassa fever among the respondents is presented in Fig. 3. Out of the total participants, 249 (36.89\%) heard about it through media, 16.15\% through family and friends while only $14.81 \%$ heard about it through health workers. 
Table 1

Socio-demographic characteristics of respondents in Iwo and Ayedire LGAs

\begin{tabular}{|c|c|c|c|c|c|c|c|}
\hline \multirow{2}{*}{ Variables } & & \multicolumn{2}{|c|}{$\begin{array}{l}\text { Iwo } \\
(n=303)\end{array}$} & \multicolumn{2}{|c|}{$\begin{array}{l}\text { Ayedire } \\
(n=372)\end{array}$} & \multicolumn{2}{|c|}{$\begin{array}{l}\text { Total } \\
(\mathrm{n}=675)\end{array}$} \\
\hline & & No & $\%$ & No & $\%$ & No & $\%$ \\
\hline \multirow[t]{2}{*}{ Gender } & Male & 159 & 52.5 & 206 & 55.4 & 365 & 54.07 \\
\hline & Female & 144 & 47.5 & 166 & 44.6 & 310 & 45.93 \\
\hline \multirow[t]{4}{*}{ Age group } & $18-24$ years & 80 & 26.4 & 94 & 25.3 & 174 & 25.78 \\
\hline & $25-39$ years & 125 & 41.3 & 136 & 36.56 & 261 & 38.67 \\
\hline & $40-59$ years & 67 & 22.1 & 96 & 25.8 & 163 & 24.15 \\
\hline & $\geq 60$ years & 31 & 10.2 & 46 & 12.4 & 77 & 11.41 \\
\hline \multirow[t]{4}{*}{ Religion } & Muslim & 105 & 34.7 & 101 & 27.2 & 206 & 30.52 \\
\hline & Christianity & 156 & 51.5 & 171 & 46 & 327 & 48.44 \\
\hline & Traditional & 26 & 8.6 & 74 & 19.9 & 100 & 14.81 \\
\hline & Others & 16 & 5.3 & 26 & 7 & 42 & 6.22 \\
\hline \multirow[t]{4}{*}{ Marital status } & Single & 118 & 38.9 & 134 & 36 & 252 & 37.33 \\
\hline & Married & 122 & 40.26 & 148 & 39.78 & 270 & 40 \\
\hline & Divorced & 46 & 15.2 & 56 & 15.1 & 102 & 15.11 \\
\hline & Widow/widower & 17 & 5.6 & 34 & 9.1 & 51 & 7.56 \\
\hline \multirow[t]{5}{*}{ Ethnicity } & Yoruba & 149 & 49.2 & 151 & 40.6 & 300 & 44.44 \\
\hline & Igbo & 80 & 26.4 & 119 & 32 & 199 & 29.48 \\
\hline & Hausa & 50 & 16.5 & 59 & 15.9 & 109 & 16.15 \\
\hline & Fulani & 20 & 6.6 & 28 & 7.5 & 48 & 7.11 \\
\hline & Others & 4 & 1.3 & 15 & 4 & 19 & 2.81 \\
\hline \multirow[t]{5}{*}{ Education } & No formal education & 36 & 1.9 & 66 & 21.78 & 102 & 15.11 \\
\hline & $<$ Secondary school & 43 & 14.2 & 64 & 17.2 & 107 & 15.85 \\
\hline & Secondary school & 88 & 29 & 111 & 29.8 & 199 & 29.48 \\
\hline & Higher college & 58 & 19.1 & 43 & 11.6 & 101 & 14.96 \\
\hline & University & 78 & 25.7 & 88 & 23.7 & 166 & 24.59 \\
\hline
\end{tabular}




\begin{tabular}{|c|c|c|c|c|c|c|c|}
\hline \multirow[b]{2}{*}{ Employment status } & \multirow[b]{2}{*}{ Not employed } & \multicolumn{2}{|c|}{$\begin{array}{l}\text { Iwo } \\
(n=303)\end{array}$} & \multicolumn{2}{|c|}{$\begin{array}{l}\text { Ayedire } \\
(n=372)\end{array}$} & \multicolumn{2}{|c|}{$\begin{array}{l}\text { Total } \\
(n=675)\end{array}$} \\
\hline & & 73 & 24.1 & 92 & 24.7 & 165 & 24.44 \\
\hline & Farming & 27 & 8.9 & 67 & 18 & 94 & 13.93 \\
\hline & Petty trading & 81 & 26.7 & 82 & 22 & 163 & 24.15 \\
\hline & Transporter & 31 & 10.2 & 47 & 12.6 & 78 & 11.55 \\
\hline & Office work & 82 & 27.1 & 81 & 21.8 & 163 & 24.15 \\
\hline & Did not disclose & 9 & 3 & 3 & 0.8 & 12 & 1.77 \\
\hline
\end{tabular}

Knowledge of the respondents about Lassa fever is presented in Table 2. Five hundred and thirty-six (79.41\%) respondents indicated their previous awareness of Lassa fever, while 139 (20.59\%) have never heard of it before. Respondents in Iwo were more aware of the transmission and symptoms of Lassa fever than respondent from Ayedire. Although, $79.41 \%$ of the respondents had heard of Lassa fever before, but only $42.52 \%$ are aware of Lassa virus as the causative agent of the disease. From the data, $185(27.41 \%)$ knew that the disease is transmitted through the consumption of rat, consumption of food contaminated with rat urine/feaces (25.48\%), direct contact with an infected person (11.70\%), while 149 $(22.07 \%)$ do not even have any idea of how the illness is transmitted. Some of the myth misconceptions about Lassa fever transmission included mosquito bit (17.63\%), dog bite (5.04\%). Common symptoms known by the respondents as associated with Lassa fever include, fatigue (31.41\%), fever (16.59\%) and general weakness (14.52\%). The least mentioned symptom was miscarriage in pregnant women (2.07\%). This study has revealed that only $0.99 \%$ of the participant in Iwo had good knowledge of Lassa fever, while none of the respondents from Ayedire had good knowledge of it. In total, $99.56 \%$ of the respondents had poor knowledge of the disease. Only $17.33 \%$ believed that victims may not show any symptom at the initial stage, $37.78 \%$ said Lassa fever is preventable, and only $41.48 \%$ believed that Lassa fever can lead to death. One hundred and seventy-nine $(26.52 \%)$ respondents believed that there is vaccine for Lassa fever. Only $69(10.22 \%)$ could correctly state the incubation period of the disease, as seven to twenty-one days. While $43.85 \%$ of the respondents will go to the hospital when they observe symptoms, $11.85 \%$ will do self-medication, and $9.04 \%$ will consult religious houses. 
Table 2

Knowledge of Lassa fever among residents of Iwo and Ayedire LGAs, Osun State, Nigeria

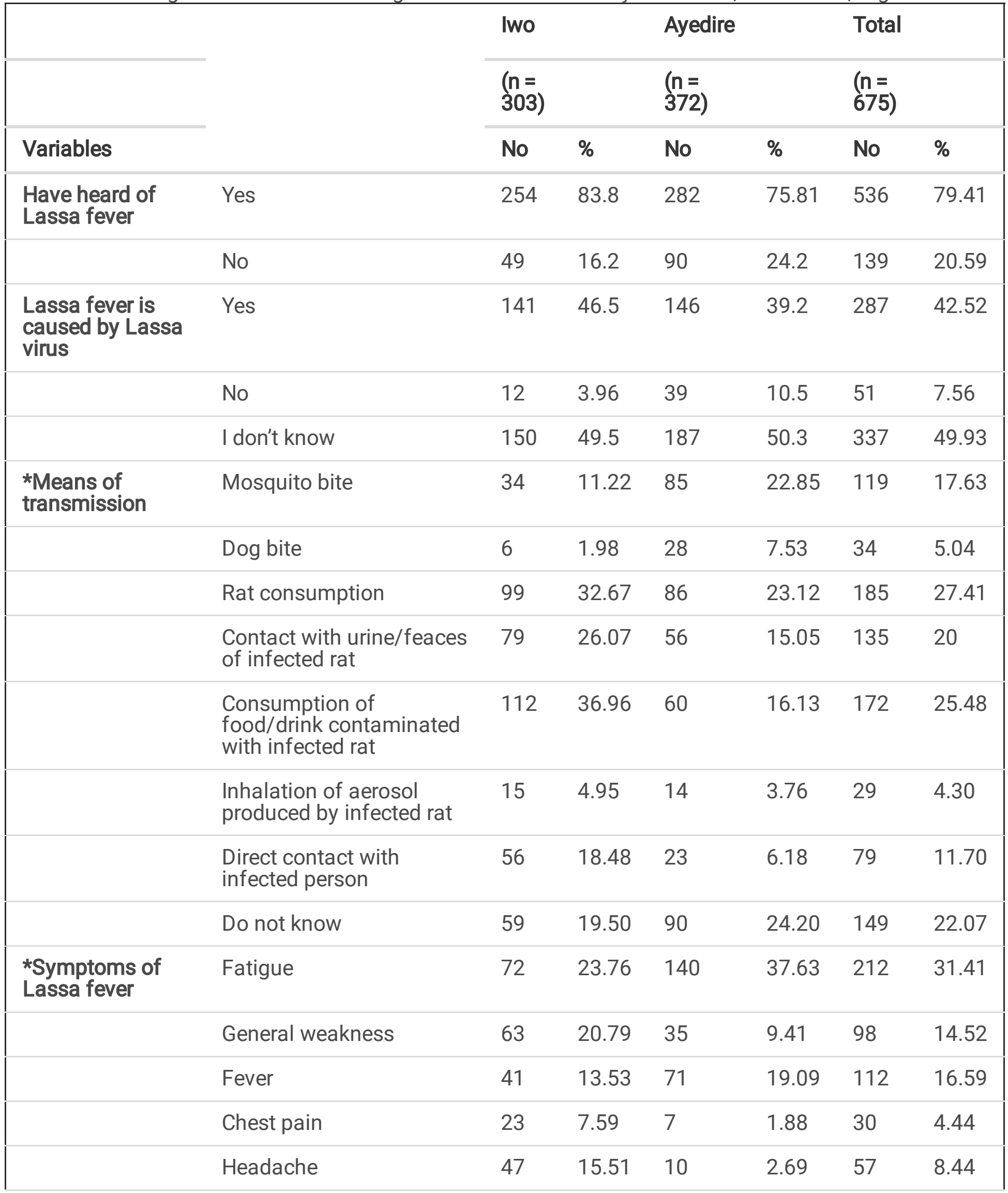

*Multiple responses were considered 


\begin{tabular}{|c|c|c|c|c|c|c|c|}
\hline & & Iwo & & Ayedire & & Total & \\
\hline & & $\begin{array}{l}(n= \\
303)\end{array}$ & & $\begin{array}{l}(n= \\
372)\end{array}$ & & $\begin{array}{l}(n= \\
675)\end{array}$ & \\
\hline \multirow[t]{10}{*}{ Variables } & & No & $\%$ & No & $\%$ & No & $\%$ \\
\hline & Sore throat & 37 & 12.21 & 5 & 1.34 & 42 & 6.22 \\
\hline & Vomiting & 50 & 16.50 & 5 & 1.34 & 55 & 8.15 \\
\hline & Diarrhea & 35 & 11.55 & 4 & 1.08 & 39 & 5.78 \\
\hline & Face swelling & 18 & 5.94 & 2 & 0.54 & 20 & 2.96 \\
\hline & Low blood pressure & 21 & 6.93 & 4 & 1.08 & 25 & 3.70 \\
\hline & $\begin{array}{l}\text { Nose/mouth/gastro } \\
\text { bleeding }\end{array}$ & 29 & 9.57 & 4 & 1.08 & 33 & 4.89 \\
\hline & $\begin{array}{l}\text { Miscarriage in pregnant } \\
\text { women }\end{array}$ & 11 & 3.63 & 3 & 0.81 & 14 & 2.07 \\
\hline & Cough & 42 & 13.86 & 2 & 0.54 & 44 & 6.52 \\
\hline & I don't know & 80 & 26.40 & 93 & 25 & 173 & 25.63 \\
\hline \multirow{3}{*}{$\begin{array}{l}\text { All victims show } \\
\text { symptoms at } \\
\text { initial stage }\end{array}$} & Yes & 117 & 38.6 & 131 & 35.2 & 248 & 36.74 \\
\hline & No & 43 & 14.2 & 74 & 19.9 & 117 & 17.33 \\
\hline & I don't know & 143 & 47.2 & 167 & 44.9 & 310 & 45.93 \\
\hline \multirow{3}{*}{$\begin{array}{l}\text { Lassa fever can } \\
\text { lead to death }\end{array}$} & Yes & 146 & 48.2 & 134 & 36 & 280 & 41.48 \\
\hline & No & 42 & 13.9 & 67 & 18 & 109 & 16.15 \\
\hline & I don't know & 115 & 38 & 171 & 45.97 & 286 & 42.37 \\
\hline \multirow{3}{*}{$\begin{array}{l}\text { There is vaccine } \\
\text { for Lassa fever }\end{array}$} & Yes & 67 & 22.1 & 112 & 30.1 & 179 & 26.52 \\
\hline & No & 76 & 25.1 & 80 & 21.5 & 156 & 23.11 \\
\hline & I don't know & 160 & 52.8 & 180 & 48.4 & 340 & 50.37 \\
\hline \multirow{3}{*}{$\begin{array}{l}\text { Lassa fever can } \\
\text { be prevented }\end{array}$} & Yes & 139 & 45.9 & 116 & 31.2 & 255 & 37.78 \\
\hline & No & 24 & 7.9 & 57 & 15.3 & 81 & 12.00 \\
\hline & I don't know & 140 & 46.2 & 199 & 53.49 & 339 & 50.22 \\
\hline
\end{tabular}




\begin{tabular}{|c|c|c|c|c|c|c|c|}
\hline \multirow[b]{3}{*}{ Variables } & & \multirow{2}{*}{\multicolumn{2}{|c|}{$\begin{array}{l}\text { Iwo } \\
(n= \\
303)\end{array}$}} & \multirow{2}{*}{\multicolumn{2}{|c|}{$\begin{array}{l}\text { Ayedire } \\
(n= \\
372)\end{array}$}} & \multirow{2}{*}{\multicolumn{2}{|c|}{$\begin{array}{l}\text { Total } \\
\\
\left(\begin{array}{l}n= \\
675)\end{array}\right.\end{array}$}} \\
\hline & & & & & & & \\
\hline & & No & $\%$ & No & $\%$ & No & $\%$ \\
\hline \multirow[t]{4}{*}{ Incubation period } & Less than 1 day & 43 & 14.2 & 71 & 19.1 & 114 & 16.89 \\
\hline & 7-21 days & 43 & 14.2 & 26 & 7.0 & 69 & 10.22 \\
\hline & Less than six months & 84 & 27.7 & 53 & 14.2 & 137 & 20.50 \\
\hline & No idea & 133 & 43.9 & 222 & 59.7 & 355 & 52.59 \\
\hline \multirow{6}{*}{$\begin{array}{l}\text { What to do if } \\
\text { symptoms occur }\end{array}$} & Go to drug house & 44 & 14.52 & 36 & 9.68 & 80 & 11.85 \\
\hline & Use local herbs & 20 & 6.6 & 18 & 4.8 & 38 & 5.63 \\
\hline & Visit herbalist & 11 & 3.63 & 31 & 8.33 & 42 & 6.22 \\
\hline & Go to religious house & 17 & 5.61 & 44 & 11.83 & 61 & 9.04 \\
\hline & Go to the hospital & 157 & 51.8 & 139 & 37.4 & 296 & 43.85 \\
\hline & I don't know & 53 & 17.5 & 104 & 28 & 157 & 23.26 \\
\hline
\end{tabular}

Prevalence of rats in the residence of participants is presented in Table 3. Approximately, forty-five percent of the respondents harbour rats in their houses every day, while only 28 (4.15\%) have not seen a rat in their residence for over 6 months. The percentage of respondents having $\geq 5$ rats in their houses was $40.15 \%$ and $33.48 \%$ described the number of rats in their houses as plenty. The response of the participants on how to prevent Lassa fever is shown in Table 4. The common methods of prevention as reported were good hygiene and a clean environment (35.26\%), blocking of rat holes around the house $(22.37 \%)$, keeping foodstuff in sealed containers $(22.93 \%)$. 
Table 3

Prevalence of rats among residents of Iwo and Ayedire Local Government Areas, Osun State, Nigeria

\begin{tabular}{|c|c|c|c|c|c|c|}
\hline \multirow[b]{2}{*}{ How often do you see rat in the house? } & \multicolumn{2}{|c|}{$\begin{array}{l}\text { Iwo } \\
(N=303)\end{array}$} & \multicolumn{2}{|c|}{$\begin{array}{l}\text { Ayedire } \\
(\mathrm{N}=372)\end{array}$} & \multicolumn{2}{|c|}{$\begin{array}{l}\text { Total } \\
(\mathrm{N}=675)\end{array}$} \\
\hline & $\mathbf{N}$ & $\%$ & $\mathbf{N}$ & $\%$ & $\mathbf{N}$ & $\%$ \\
\hline Everyday & 128 & 42.2 & 176 & 47.3 & 304 & 45.04 \\
\hline $2-7$ days & 49 & 16.2 & 65 & 17.5 & 114 & 16.89 \\
\hline $8-30$ days & 58 & 19.14 & 75 & 20.20 & 133 & 19.70 \\
\hline $1-3$ months & 27 & 8.91 & 20 & 5.4 & 47 & 6.96 \\
\hline $3-6$ months & 33 & 10.9 & 16 & 4.3 & 49 & 7.26 \\
\hline$>6$ months & 6 & 2.6 & 20 & 5.4 & 28 & 4.15 \\
\hline \multicolumn{7}{|l|}{ Number of rats in the house } \\
\hline $1-5$ & 108 & 35.6 & 163 & 43.8 & 271 & 40.15 \\
\hline $6-10$ & 57 & 18.8 & 73 & 19.6 & 130 & 19.26 \\
\hline Plenty & 108 & 35.6 & 118 & 31.7 & 226 & 33.48 \\
\hline Did not disclose & 30 & 9.9 & 18 & 4.8 & 48 & 7.11 \\
\hline
\end{tabular}

One hundred and two respondents (19.70\%) believed the disease could be prevented by washing of hands often, avoidance of rat consumption (17.93\%), disposal of garbage away from homes $(13.78 \%)$ and only $85(12.59 \%)$ accepted that Lassa fever can be prevented by avoidance of contact with an infected person (Table 4). The least mentioned was the avoidance of bush burning by $72(10.67 \%)$ respondents. The knowledge of good prevention practices in Iwo and Ayedire LGAs was $12.21 \%$ and $2.15 \%$, respectively. This implies that $93.33 \%$ of the respondents showed poor prevention practices. The knowledge of prevention practices is regarded as poor in both Local Government areas, but Iwo LGA showed better knowledge of good prevention practices than Ayedire. 
Table 4

Responses on prevention of Lassa fever in Iwo and Ayedire Local Government Areas

\begin{tabular}{|c|c|c|c|c|c|c|}
\hline \multirow[b]{2}{*}{ Means of prevention } & \multicolumn{2}{|c|}{$\begin{array}{l}\text { Iwo } \\
(\mathrm{N}=303)\end{array}$} & \multicolumn{2}{|c|}{$\begin{array}{l}\text { Ayedire } \\
(\mathrm{N}=372)\end{array}$} & \multicolumn{2}{|c|}{$\begin{array}{l}\text { Total } \\
(\mathrm{N}=675)\end{array}$} \\
\hline & $\mathbf{N}$ & $\%$ & $\mathbf{N}$ & $\%$ & $\mathbf{N}$ & $\%$ \\
\hline Blocking all rat holes around the house & 106 & 34.98 & 45 & 12.10 & 151 & 22.37 \\
\hline Frequent hand washing & 71 & 23.43 & 31 & 8.33 & 102 & 19.70 \\
\hline $\begin{array}{l}\text { Avoidance of frequent touching eye, nose and } \\
\text { mouth }\end{array}$ & 56 & 18.48 & 28 & 7.53 & 84 & 12.44 \\
\hline Keeping food in sealed containers & 102 & 33.66 & 46 & 12.37 & 148 & 21.93 \\
\hline Good hygiene and clean environment & 125 & 41.25 & 113 & 30.38 & 238 & 35.26 \\
\hline Avoidance of rat consumption & 80 & 26.40 & 41 & 11.02 & 121 & 17.93 \\
\hline Avoidance of bush burning & 33 & 10.89 & 39 & 10.48 & 72 & 10.67 \\
\hline Disposal of garbage away from homes & 66 & 21.78 & 27 & 7.26 & 93 & 13.78 \\
\hline Avoidance of contact with infected person & 61 & 20.13 & 24 & 6.45 & 85 & 12.59 \\
\hline No idea & 52 & 17.16 & 93 & 25.00 & 145 & 21.48 \\
\hline
\end{tabular}

Logistic regression analysis showed that respondents aged 25-39 years were significantly more aware of Lassa fever than other age groups. Although, there no significant difference between level of education and knowledge of $L F$, there was a positive significant relationship with good prevention practices against Lassa fever and higher education $(P<0.01)$. Also, married respondents showed positive relationship with good prevention practices and was significant at $P<0.001$. There was a significant level of relationship $(\mathrm{P}<0.01)$ between poor prevention practices and poor rat control among the respondents.

\section{Discussion}

Lassa fever could soon become a global concern if nothing is done to curtail the disease in the endemic regions. This is because, it can be imported from endemic areas to other countries [12,32,33]. More than 867 people have died of LF in Nigeria in recent years with CFR ranging between 3.64\% and 27.2\% [4]. Despite the alarming increase in CFR, its awareness and knowledge are underdetermined in many local communities within the country. Poor/inadequate knowledge and wrong preventive practices could aid the spread of infectious diseases among people. Poor epidemic preparedness has been indicated as one of the key factors contributing to disease outbreak $[34,35]$. Therefore, it is necessary to investigate the level of awareness, knowledge, and prevention practices among the people about the disease, especially in the local communities where they are more prone to Lassa fever because of the prevalence of rodents 
$[1,3]$. In this study, $79.41 \%$ of the respondents were aware of Lassa fever, which is higher than $36 \%$ and 7.4\%, as reported by Asogun et al. [36] and Oladeinde et al. [11], respectively in similar studies in Nigeria. Although, there has not been any formal report of Lassa fever infection in the study area, the high number of awareness among the respondents could be attributed to an increase in awareness through mass media over time. The finding of this study is close to the report of Morgan et al. [26], who recorded $90.8 \%$ awareness of LF among rural dwellers in Akwa-lbom State, southern Nigeria. From the response of the participants, it was observed that more males had heard about Lassa fever than females, which is similar to the findings of Oladeinde et al. [11]. Usuwa et al. [37] reported that $63.2 \%$ of the female respondents heard of Lassa fever before a particular study in Ebonyi State, southeast Nigeria, which is contrary to the findings of this study. More awareness about LF among male compared to female respondents in the study area could be attributed to the fact that males have access to health-related information than females [11]. The age range between 25 years and 39 years were more aware of the disease. This agrees with the report of Tobin et al. [3]. It has been discovered that this age group (25-39) give more attention to social media information than any other age group. The present study showed that the percentage of the participants who had up to secondary school was similar in both towns (Iwo 29\%, Ayedire 29.8\%). In similar studies carried out in Nigeria by Morgan et al. [26] and Usuwa et al. [37], they reported $43.9 \%$ and $51.7 \%$ of participants with secondary school education, respectively. Gender, age, marital status, education, and occupation did not significantly affect the level of knowledge in the study areas. More Christians have heard of LF, probably because church leaders are interested in the well-being of their members and they often organize health promotion programs [38].

The participants heard about LF through media (36.89\%), family and friends (16.15\%), health workers (14.81\%), while $20.15 \%$ of the participants never heard about the disease. Low information from health workers could be ascribed to their poor knowledge about the disease $[3,6]$. Mass media being the most common means of hearing about LF in the study area may not be far-fetched from the fact that many people in the local communities have battery-powered radios which they use to receive information because of the peculiarity of poor electricity supply. Publicity jingles via radio must have increased the awareness of the people over time. Mass media as the most popular means of hearing about the disease is in agreement with many researchers [11, 26, 37]. Despite the high awareness, some of the respondents believed that Mosquito bites (17.63\%) and dog bites (5.04\%) could be possible means of transmission of the disease. Oladeinde et al. [11] reported in a similar study in rural communities of Edo State, Southern Nigeria that $67.8 \%$ and $20.7 \%$ of the respondents had misconceptions about the cause of LF to be mosquito bites and dog bites, respectively. The symptoms most correctly known by the participants include fatigue (31.41\%), fever (16.59\%), and general weakness (14.52). This is contrary to the report of Usuwa et al. [37], who reported the percentage of respondents known symptoms to be fever (69.3\%), and general weakness (65\%). Only $41.48 \%$ believed the disease could lead to death, $37.78 \%$ believed it can be prevented, $26.52 \%$ signified that there is a vaccine for LF. Only $10.22 \%$ of the participants could correctly state the incubation period as $7-21$ days, $37.19 \%$ do not have adequate knowledge about the incubation period of the disease, and $52.59 \%$ had no idea of the incubation period. The proportion of respondents who will go for self-medication, such as the use of un-prescribed drugs and local herbs was $17.48 \%$, 
consultation of an herbalist (6.22\%), visiting religious houses (9.04\%), and only $43.85 \%$ will go to the hospital if symptoms occur. Self-medication could prolong illnesses, lead to more complications, easy spread to other people, more expensive to treat, extend hospital stay, and even death in some cases [39]. Although, a high level of awareness was reported for Ayedire and slightly higher in Iwo, 672 (99.96\%) of the respondents have poor knowledge of the disease. Only $25.48 \%$ were able to identify consumption of food/drink contaminated with urine/feaces of an infected rat as a means of transmission of LF, while $22.07 \%$ of the respondents do not have an idea of the means of transmission of the disease. This is below the findings of Morgan et al. [26], who reported that $88 \%$ of the respondents in a similar study in Nigeria associate the transmission of LF with eating food contaminated with rats' feaces and urine. Good knowledge of the disease cannot be over-emphasized in curtailing the spread during an outbreak.

Although, $7.26 \%$ of the respondents have seen rats in their homes in more than 3 months, $45.04 \%$ sees rats in their house every day and $33.48 \%$ could quantify the number of rats in their residence as plenty. This study showed that $92.89 \%$ of the respondents harbours rats in their homes, which implies that they do not have effective measures to control rats in their homes. The role of rats in the spread of LF cannot be over-emphasized. Although a high percentage of the respondents identified good hygiene and clean environment (35.26\%) as a preventive measure against the disease, only $22.37 \%$ agree they should block rat holes while $21.93 \%$ believed they should keep their food items in sealed containers. Good prevention practices can restrict the spread of infectious diseases from endemic regions to other regions.

Part of the factors that could aid the spread of LF in an outbreak include lack of diagnostic facility in the rural areas, LF symptoms similar to other febrile illnesses, such as malaria and typhoid fever, thus leading to late presentation, un-curtailed rats in homes, poor knowledge, and poor prevention practices $[1,7,11$, $17,25]$. Although, early diagnosis will help reduce spread, diagnostic facilities are difficult to find in many rural communities in Africa, as none could be found in the study areas. Lack of proper barrier, infection prevention, and control practices exposes health workers to infection [22, 27]. Inter-border communal trade of farm produce within local communities, which is characterized by overcrowding and poor sanitation, could also aid the spread of Lassa fever in poorly informed communities. Spreading of semiprocessed foods along the walk path to dry is a common practice in rural areas and this has been observed to invite rodents, thereby enhances the deposition of rat excreta/urine on such foods [11]. Bush burning facilitates unfettered migration of rodents from bush to residential apartments. Burning of bush is an unwholesome practice, especially in the dry season (November- April) and this could also be responsible for prevalent outbreaks recorded during the dry season. Due to poor surveillance in many parts of the country and some of the aforelisted factors, some residents of these local communities would have died as a result of undiagnosed LF infection.

\section{Conclusions}

Gender, age, marital status, education, and occupation did not significantly affect the level of knowledge about Lassa fever in Iwo and Ayedire Local Government Areas, Osun State, Nigeria. Although, $79.41 \%$ of the respondents are aware of Lassa fever, only $0.44 \%$ had good knowledge of the transmission and 
symptoms of the disease. Less than $50 \%$ of the respondents will go to the hospital if they observe symptoms. Accessing information through health workers is very poor. Despite the knowledge of Mastomys rats as the primary reservoir of the Lassa fever virus, $45.04 \%$ of the respondents do not have effective means of preventing rats into their homes. Only $22.37 \%$ will block rat holes around their homes, $21.93 \%$ will keep their food in sealed containers, $17.93 \%$ will avoid consumption of rat and $10.67 \%$ will avoid bush burning. More than $90 \%$ of the respondents showed poor knowledge of prevention practices in the study areas. Public awareness enlightenment campaign is a key factor in the prevention and control of Lassa fever outbreak. It is also important to promote awareness about the role of rats in the transmission and spread of Lassa fever. The findings of this study show that there is a low level of knowledge of Lassa fever among the studied population and there is a need for further health education campaigns to improved environmental hygiene and adjustment of practices that could promote the spread of Lassa fever.

\section{Recommendations}

It is important for the Government to work through the health workers to sensitize the populace on the transmission, symptoms, and prevention of Lassa fever, with more focus on the rural communities, where Mastomys rats are much more prevalent. There should be a community awareness campaign on the role of rats in the spread of Lassa fever. The importance of good hygiene and good prevention practices should also be emphasized. People should be encouraged to go to the hospital immediately after they notice any symptom, so as to curtail the spread of the disease. This can also be possible by building more community health centers with appropriate diagnosing equipment. Healthcare workers should be educated on safety preventive measures of infectious diseases and adequate personal protection equipment (PPE) should be made available for their use. Patients presenting with febrile illness with associated symptoms should be handled with extra care.

\section{Declarations}

\section{Ethical Approval and Consent to participate}

The approval for this study was received from the Research and Ethics Committee of Bowen University, Iwo, Nigeria. Also, the consent of the respondents was received before the interview and they were also promised to keep their response anonymous and confidential.

\section{Consent for publication}

Not applicable

\section{Availability of supporting data}

The dataset supporting the conclusion of this article is included as addition file 


\section{Competing Interest}

The author declares no conflict of interest.

\section{Funding}

Not applicable

\section{Authors' Contribution}

The author designed the work, analyzed the data and wrote the manuscript.

\section{Acknowledgements}

The authors are grateful to the research assistants, Mayowa Oni and Linda C. Agbsianya for administering the questionnaire and the respondents, for their valuable time given in responding to the questionnaire. The effort of Mrs. Grace Popoola is gratefully appreciated, for assisting with the statistical analyses.

\section{Authors' Information}

Microbiology Unit,

College of Agriculture, Engineering and Science,

Bowen University,

Iwo, Osun State,

Nigeria.

olukemi.aromolaran@bowen.edu.ng

$+2348062225745$

\section{References}

1. Ogbu O, Ajuluchukwu E, Uneke CJ. Lassa fever in West African Sub-region: an overview. J Vect Borne Dis. 2007;44:1-11.

2. Khan SH, Goba A, Chu M, Roth C, Healing T, Marx A, et al. New opportunities for field research on the pathogenesis and treatment of Lassa fever. Antiviral Res. 2008;78:103-15.

3. Tobin EA, Asogun DA, Isah EC, Ugege OG, Ebhodagbe P. Assessment of knowledge sand attitude towards Lassa fever among primary health care providers in an endemic suburban community of Edo State: implication for control. J Med Med Sci. 2018;4(8):311-8. 
4. Center for Disease Control and Prevention. Lassa fever. https://www.cdc.gov/vhf/lassa/index.html 2019. Accessed 20 October 2020.

5. Yun NE, Walker DH. Pathogenesis of Lassa fever. Viruses. 2012;4:2031-48.

6. Ijarotimi IT, Ilesanmi OS, Aderinwale A, Abiodun-Adewusi O, Okon I. Knowledge of Lassa fever and use of infection prevention and control facilities among health workers during Lassa fever outbreak in Ondo State, Nigeria. Pan Afri Med J. 2018;30:56.

7. Akpede GO, Asogun DA, Okogbenin SA, Dawodu SO, Momoh MO, Dango AE, Ike C, Tobin E, et al. Caseload and case fatality of Lassa fever in Nigeria, 2001-2018: A specialist Center's Experience and its implication. Front Public Health. 2019;7:170-88.

8. Bowen MD, Rollin PE, Ksiazek TG, Hustad HL, Bausch DG, Demby AH, et al. Genetic diversity among Lassa virus strains. J Virol. 2000;74:6992-7004.

9. Kelly JD, Barrie MB, Ross RA, Temple BA, Moses LM, Bausch DG. Housing equity for health equity: a rights-based approach to the control of Lassa fever in post-war Sierra Leone. BMC Int Health Hum Rights. 2013;13:2-7.

10. Fichet-Calvet E, Rogers DJ. Risk Maps of Lassa fever in West Africa. PLoS Negl Trop Dis. 2009;3(3):e388.

11. Oladeinde $\mathrm{BH}$, Omoregie R, Odia I. Public awareness of Lassa fever in three rural communities of Nigeria. Int J Health Promot Educ. 2015;53(3):128-35.

12. Gunther S, Emmerich T, Laue 0 , Kuhle M, Asper A, Jung T, et al. Imported Lassa fever in Germany: Molecular characterization of a new Lassa virus strain. Emerg Infect Dis. 2000;6:466-76.

13. Atkin S, Anaraki S, Gothard P, Walsh A, Brown D, Gopal R, et al. The first case of Lassa fever imported from Mali to the United Kingdom, February 2009. Euro Surveill. 2009;14:19145.

14. Bonwitt J, Saez AM, Lamin J, Ansumana R, Dawson M, Buanie J, et al. At Home with Mastomys and Rattus: Human-Rodent Interactions and Potential for Primary Transmission of Lassa Virus in Domestic Spaces. Am J Trop Med Hyg. 2017;96(4):935-43.

15. Olayemi A, Oyeyiola A, Obadare A, Igbokwe J, Adesina AS, Onwe F, et al. Widespread arenavirus occurrence and seroprevelence in small mammals, Nigeria. Parasit Vectors. 2018;11:416.

16. Dan-Nwafo CC, Ipadeola O, Smout E, llori E, Adeyemo A, Umaokonkwo C, et al. A cluster of nosocomial Lassa fever cases in a tertiary health facility in Nigeria: Description and lesson learned, 2018. Int J Infect Dis. 2019;83:88-94.

17. Richmond JK, Baglole DJ. Lassa fever: epidemiology, clinical features and social consequences. BMJ. 2003;327:1271-5.

18. Tambo E, Adetunde OT, Olalubi OA. Re-emerging Lassa fever outbreak in Nigeria: Re-enforcing "One Health" community surveillance and emerging response practice. Infect Dis Poverty. 2018;7:37-43.

19. Stephenson EH, Larson EW, Dominik JW. Effect of environmental factors on aerosol-induced Lassa virus infection. J Med Virol. 1984;14(4):295-303. 
20. Branco LM, Boisen ML, Anderson KG, Grove JN, Moses LM, Muncy IJ. Lassa hemorrhagic fever in a late term pregnancy from northern Sierra Leone with a positive maternal outcome: a case report. Virol J. 2011;8:404-17.

21. Center for Disease Control and Prevention. Lassa fever. https://www.cdc.gov/vhf/lassa/transmission/index.html 2014. Accessed 17 October 2020.

22. World Health Organization. Lassa fever. https://www.who.int/news-room/fact-sheets/detail/lassafever 2017 Accessed 10 July 2020.

23. World Health Organization. Lassa fever. https://www.who.int/csr/disease/lassafever 2018 Accessed 21 October 2020.

24. Balkhy HH, Abolfotouh MA, Al-Hathlool RH, Al-Jumah MA. Awareness, attitude and practices related to the swine influenza pandemic among the Saudi Public. BMC Infect Dis. 2010;10:42-8.

25. Oboratare O, Chukwuyem A, Emmanuel O, Obekpa AS. Housing factors and transmission of Lassa fever in a rural area of south-south Nigeria. General Health Med Sci. 2014;1(2):15-20.

26. Morgan EA, Amos ET, Divine AC, lbong AE, Mfon ME, Anieti MH, et al. Knowledge and prevention of Lassa fever among adults in a rural community in southern Nigeria. Saudi J Med. 2018;3(7):393-9.

27. Ndu AC, Kassy WC, Ochie CN, Arinze-Onyia SU, Okeke TA, Aguwa EN. Knowledge, Misperception and Barriers towards Lassa Fever Control among Health Care Workers in a Tertiary Intitution in Enugu, Nigeria. J Health Care Poor Underserved. 2019;30(3):1151-64.

28. Nigeria Center for Disease Control. Lassa Fever Situation Report. https://www.ncdc.gov.ng. Accessed 20 June 2020.

29. McCormick JB, King IJ, Webb PA, Scribner CL, Craven RB, Johnson KM, et al. Lassa fever: Effective therapy with Ribavirin. N Engl J Med. 1986;314(1):20-6.

30. McCormick JB, Webb PA, Krebs JW, Johnson KM, Smith ES. A prospective study of the epidemiology and ecology of Lassa fever. J Infect Dis. 1987;155:437-44.

31. National Population Commission of Nigeria (NPC). Population and housing census of the Federal Republic of Nigeria. 2006. Available from: http://www.population.gov.ng. Accessed 20 June 2020.

32. Brosh-Nissimov T. Lassa fever: another threat from West Africa. Disaster Mil Med. 2016;2:8.

33. Lehmann C, Kochanek M, Abdulla D, Beckar S, Boll B, Bunte A. Control measures following a case of reported Lassa fever from Togo, North Rhine Westphalia, Germany, 2016. Euro Surveill. 2017;22(39):17-00088.

34. Adebimpe WO. Knowledge and preventive practices against Lassa fever among primary health care workers in Osogbo. Univ Mauritus Res J. 2015;21:579-94.

35. World Health Organization. Factors that contribute to undetected spread of Ebola virus and impeded rapid containment. Https://www.who.int/csr/disease/ebola/one-year-report/factors/en/. Accessed 22 October 2020.

36. Asogun DA, Adomeh DI, Ehimuan J, Odia I, Hass M, Gabriel M, et al. Molecular diagnostics for Lassa fever at Irrua specialist teaching hospital, Nigeria: lesson learnt from two years of laboratory 
operation. PLoS Negl Trop Dis. 2012;6(9):e1839.

37. Usuwa IS, Akpa CO, Umeokonkwo CD, Umoke MJ, Oguanuo CS, Olorukooba AA. Knowledge and risk perception towards Lassa fever infection among residents of affected communities in Ebonyi State, Nigeria: implication for risk communication. BMC Public Health. 2020;20:217.

38. Rivera-Hernandez M. The role of religious leaders in health promotion for older Mexicans with diabetics. J Relig Health. 2015;54(1):303-15.

39. Ateshim Y, Bereket B, Major F, Emun Y, Woldai B, Pasha I. Prevalence of self-medication with antibiotics and associated factors in the community of Asmara, Eritrea: a descriptive cross sectional survey. BMC Public Health. 2019;19:726.

\section{Figures}




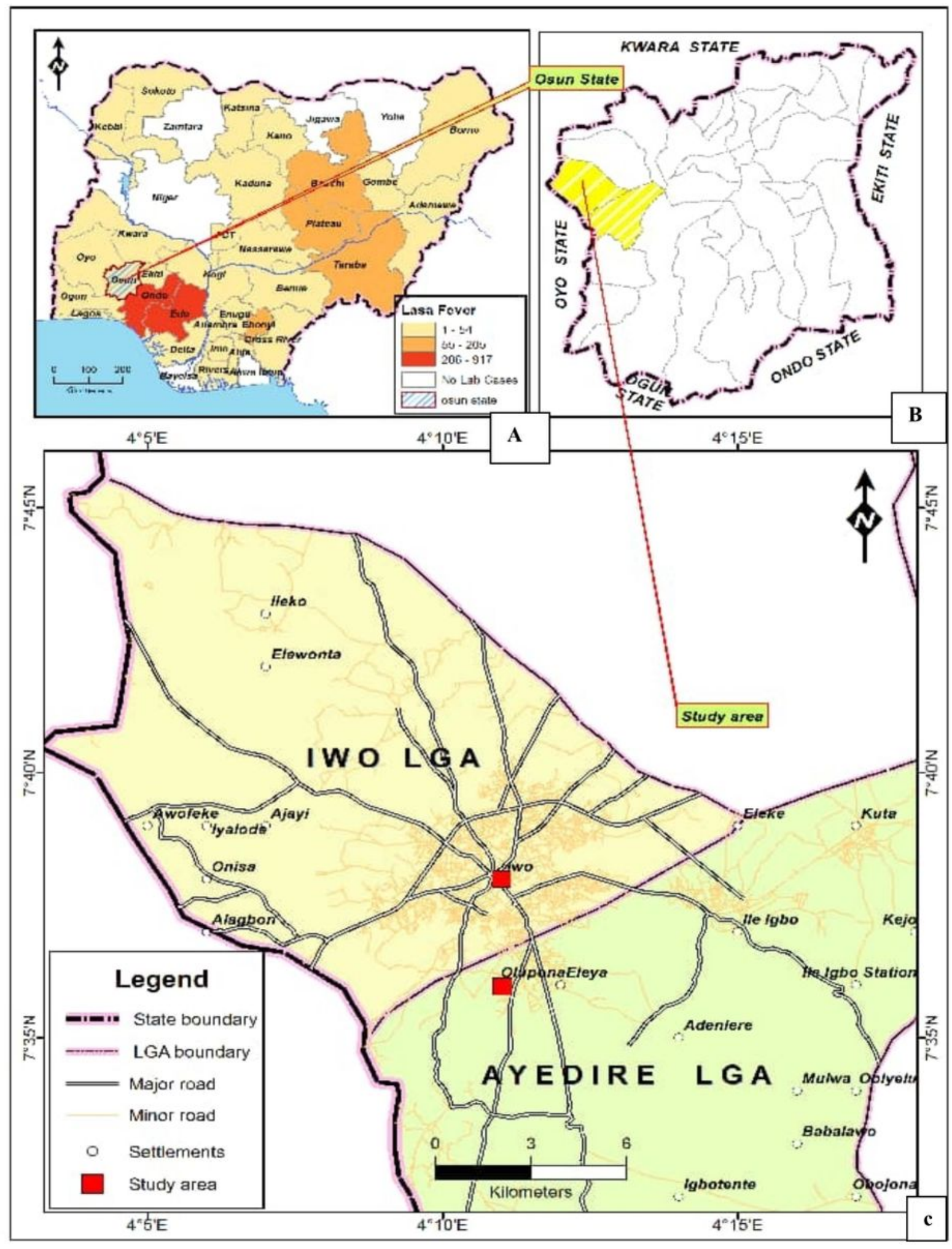

\section{Figure 1}

Maps of Nigeria showing Lassa fever endemic States [A]; Osun State [B] and study area [C] Note: The designations employed and the presentation of the material on this map do not imply the expression of any opinion whatsoever on the part of Research Square concerning the legal status of any country, territory, city or area or of its authorities, or concerning the delimitation of its frontiers or boundaries. This map has been provided by the authors. 


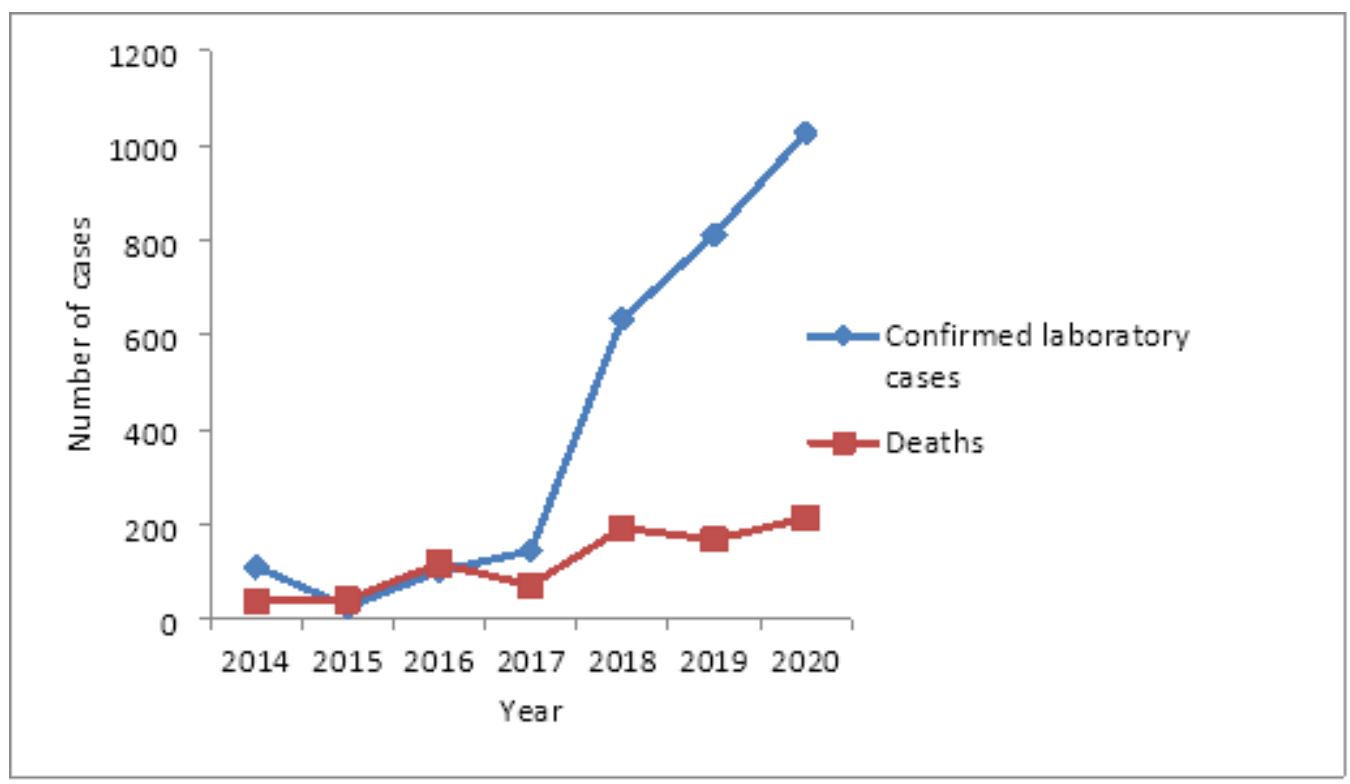

Figure 2

Number of confirmed laboratory cases of Lassa fever and deaths recorded annually from 2014 to 2020 *The first twenty-three weeks for year 2020 Data source - www.ncdc.gov.ng; accessed June 6th, 2020

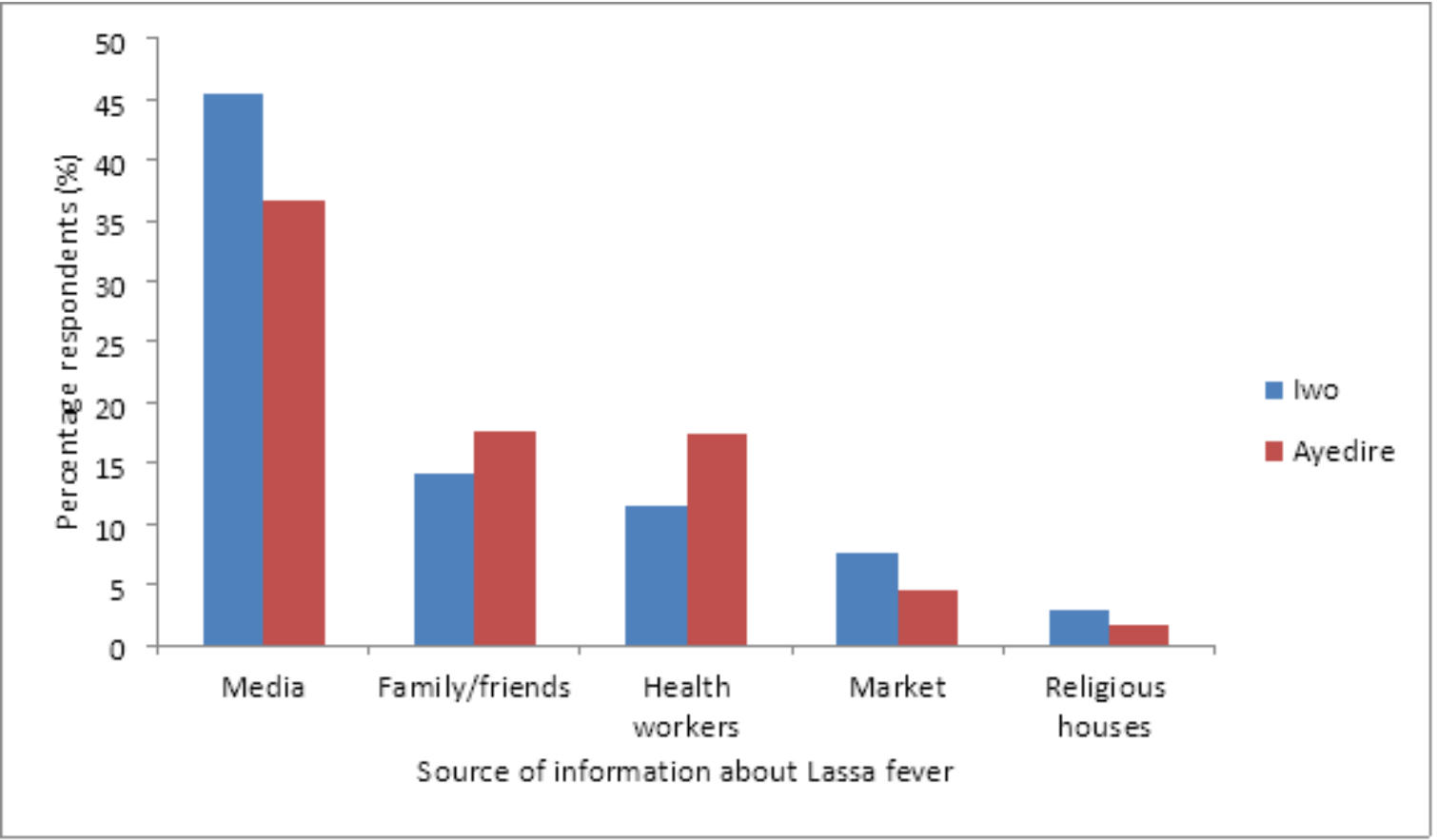

\section{Figure 3}

Source of information about Lassa fever among residents of Iwo and Ayedire Local Government Areas, Osun State, Nigeria

\section{Supplementary Files}

This is a list of supplementary files associated with this preprint. Click to download. 
- SupportingFile.xIsx

Page 22/22 